Dept. of Animal Hygiene and Zoonoses,

Fac. Vet. Medicine, Assiut Univ.

\title{
EPIDEMIOLOGICAL STUDY ON BRUCELLOSIS IN ANIMALS AND MAN IN NEW VALLEY GOVERNORATE \\ (With 13 Tables)
}

\author{
By \\ AMAL S.M. SAYED; A.A. ISMAIL and \\ *EBTSAM M. OMRAN
}

*Animal Health Research Institut New Valley Governorate (Received at 8/5/2010)

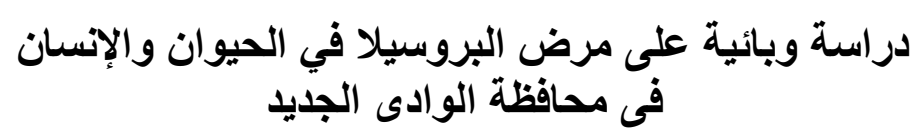

أمل سبي محد سبي ، عبل المعز أحدد إسعاعيل ، إبتسام عمران

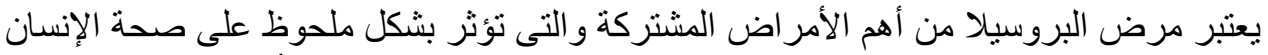

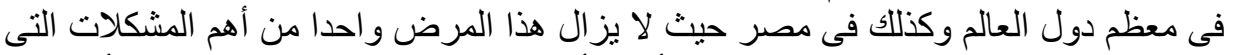

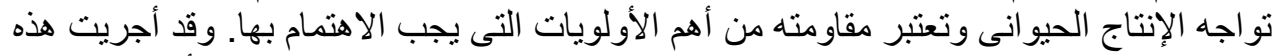

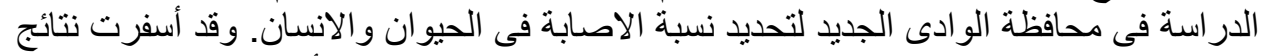

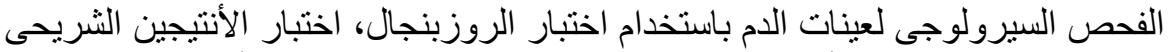

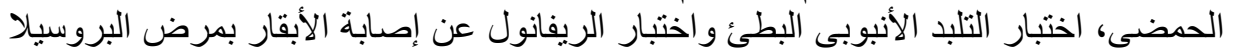

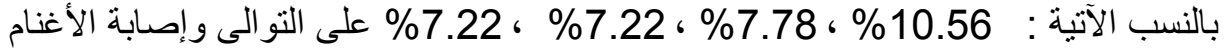

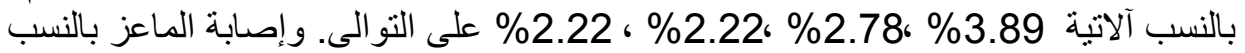

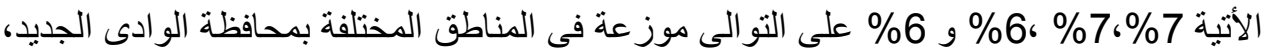

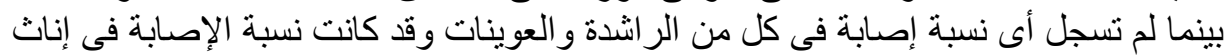

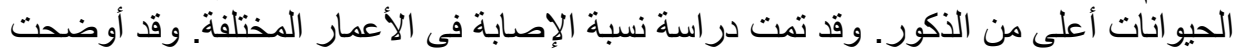

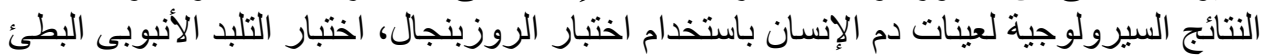

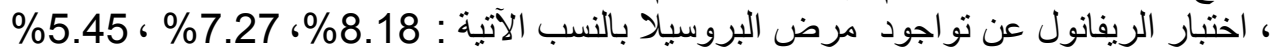

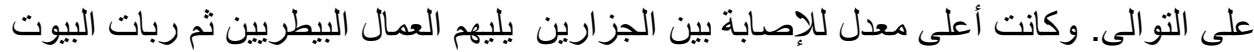

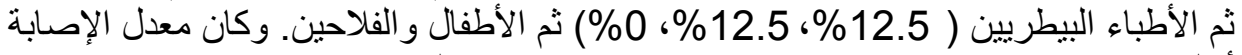

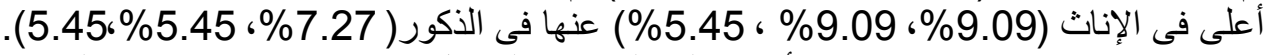
وقد تمت در اسة نسبة الإصابة فى الأعمار المختلفة. وسجلت كل نتائج الإصابة بين سكان الركان ولم تسجل أى منها بين سكان المدن. 


\section{SUMMARY}

Brucellosis in Egypt is still one of the most serious problems facing animal production. This study aimed at detection of brucellosis in animals and man in New Valley Governorate. Serum samples of cattle, sheep, goats and camels were examined by Rose Bengal plate test, buffered acidified plate antigen test, tube agglutination test and Rivanol test. Serological examination of blood samples revealed that the prevalence of brucellosis among cattle, sheep and goat by using RBPT, BAPAT, TAT and RT was $(10.56 \%, 7.78 \%, 7.22 \%$ and $7.22 \%),(3.89 \%, 2.78 \%, 2.22 \%$ and $2.22 \%)$, $(7 \%, 7 \%, 6 \%$ and $6 \%)$. Brucellosis could not be detected in El-Rashda and El-Owinat. The infection was higher in female than males. The infection rate of brucellosis was studied in different ages. Brucellosis could not be detected in camels. The results of human screening by using RBPT, TAT \& RT revealed a prevalence of brucellosis with rates of $8.18 \%, 7.27 \%$ and $5.45 \%$, respectively. The majority of human cases occurred in butchers, veterinary attendants, housewives, veterinarians, children and farmers. The prevalence was higher in females $(9.09 \%, 9.09 \%$ \& $5.45 \%)$ than males $(7.27 \%, 5.45 \%$ \& $5.45 \%)$. The human age-wise was found maximum at age group $21-40$ years $(11.11 \%, 9.52 \% \& 6.35 \%)$ followed by age $6-20$ years $(8.33 \%, 8.33 \% \& 8.33 \%)$ then age $41-60$ years $(5.56 \%, 5.56 \% \&$ $5,56 \%)$ and could not be detected at age group $>60$ years. All human cases were detected in rural areas.

Key words: Brucellosis, serological tests, cattle, sheep, goat, camel, man.

\section{INTRODUCTION}

Brucellosis is a widespread zoonotic disease in countries bordering the Mediterranean littoral and is responsible for enormous economic losses as well as considerable human morbidity in endemic areas (Alton, 1990 and Boschiroli et al., 2001). The disease in animals causes abortion in the last third of pregnancy, retained placenta, weak newborn at birth and reduction of milk yield. It is transmitted to human via direct contact with livestock and infected organs from diseased animals or through drinking unpasteurized milk from infected animals. In man brucellosis is characterized by undulant fever, headache, fatigue, joint and bone pain, psychotic disturbances and other symptoms (Refai, 2003).

The data published indicate clearly that brucellosis is endemic in animals in Egypt and the number of human cases is increasing (Refai, 2003). This work was designed to detect the prevalence of brucellosis among farm animals and man in New Valley Governorate by using 
different serological tests. The risk factors affecting animal and human infection with brucellosis has been studied.

\section{MATERIALS and METHODS}

\section{Animals samples:}

560 serum samples were collected from different species of animals constituting 180 samples from each of cattle and sheep and 100 samples from each of goats and camels. Information sheets were designed for each animal to record species, age, sex, history of abortion, retained placenta and stillbirth. Samples were collected from farms and abattoirs from different localities in New Valley Governorate including El-Farafra, El-Owinat, Gharb-El-Mouhoub, El-Hendaw, Mout, El-Qasr and El- Rashda.

\section{Human samples:}

110 human serum samples were collected from veterinarians and veterinary attendants (15), farmers (22), abattoir workers (6), housewives (36) technicians and nurses (16) and children (15) in New Valley Governorate. A questionnaire was designed for each individual to determine the risk factors with specific emphasis to age, sex, type of work and residence. The present study was carried out during the period between November 2005 and May 2007.

\section{Serological tests:}

Rose Bengal Plate Test (RBPT), Buffered Acidified Plate Antigen Test (BAPAT), Tube Agglutination Test (TAT), Rivanol Test (RT) and Enzyme Linked Immunosorbent Assay (ELISA) were used to detect brucellosis in animals and humans serum (Alton, 1990).

\section{RESULTS}

Table 1: Seroprevalence of brucellosis among farm animals in New Valley Governorate

\begin{tabular}{|c|c|c|c|c|c|c|c|c|c|}
\hline \multirow{2}{*}{$\begin{array}{c}\text { Type of } \\
\text { animal }\end{array}$} & \multirow{2}{*}{ Samples } & \multicolumn{2}{|c|}{ RBPT } & \multicolumn{2}{|c|}{ BAPAT } & \multicolumn{2}{|c|}{ TAT } & \multicolumn{2}{c|}{ RT } \\
\cline { 3 - 11 } & + & $\%$ & + & $\%$ & + & $\%$ & + & $\%$ \\
\hline Cattle & 180 & 19 & 10.56 & 14 & 7.78 & 13 & 7.22 & 13 & 7.22 \\
\hline Sheep & 180 & 7 & 3.89 & 5 & 2.78 & 4 & 2.22 & 4 & 2.22 \\
\hline Goat & 100 & 7 & 7 & 7 & 7 & 6 & 6 & 6 & 6 \\
\hline Camel & 100 & - & - & - & - & - & - & - & - \\
\hline
\end{tabular}


Table 2: Prevalence of brucellosis among the examined animals in relation to sex

\begin{tabular}{|l|c|c|c|c|c|c|}
\hline \multirow{2}{*}{ Test } & \multicolumn{3}{|c|}{ Male } & \multicolumn{3}{c|}{ Female } \\
\cline { 2 - 7 } & Cattle & Sheep & Goat & Cattle & Sheep & Goat \\
\cline { 2 - 7 } & No./50 & No./67 & No./35 & No./130 & No./113 & No./65 \\
\hline RBPT & $2(4 \%)$ & $1(1.49 \%)$ & - & $17(13.08)$ & $6(5.31 \%)$ & $7(10.77 \%)$ \\
\hline BAPAT & $1(2 \%)$ & - & - & $13(10 \%)$ & $5(4.42 \%)$ & $7(10.77 \%)$ \\
\hline TAT & $1(2 \%)$ & - & - & $12(9.23 \%)$ & $4(3.54 \%)$ & $6(9.23 \%)$ \\
\hline RT & $1(2 \%)$ & - & - & $12(9.23 \%)$ & $4(3.54 \%)$ & $6(9.23 \%)$ \\
\hline
\end{tabular}

Table 3: Prevalence of brucellosis among cattle in relation to location

\begin{tabular}{|l|c|c|c|c|c|c|c|c|c|}
\hline \multirow{2}{*}{\multicolumn{1}{c|}{ Location }} & \multirow{2}{*}{ Samples } & \multicolumn{2}{c|}{ RBPT } & \multicolumn{2}{c|}{ BAPAT } & \multicolumn{2}{c|}{ TAT } & \multicolumn{2}{c|}{ RT } \\
\cline { 3 - 10 } & & + & $\%$ & + & $\%$ & + & $\%$ & + & $\%$ \\
\hline El-Rashda & 18 & - & - & - & - & - & - & - & - \\
\hline Mout & 12 & 1 & 8.33 & 1 & 8.33 & 1 & 8.33 & 1 & 8.33 \\
\hline El-Farafra & 33 & 6 & 18.18 & 4 & 12.12 & 4 & 12.12 & 4 & 12.12 \\
\hline El-Hendaw & 32 & 8 & 25 & 6 & 18.75 & 5 & 15.63 & 5 & 15.63 \\
\hline El-Owinat & 45 & - & - & - & - & - & - & - & - \\
\hline El-Qasr & 16 & 1 & 6.25 & - & - & 1 & 6.25 & 1 & 6.25 \\
\hline Gharb El-Mouhoub & 24 & 3 & 12.5 & 3 & 12.5 & 2 & 8.33 & 2 & 8.33 \\
\hline
\end{tabular}

Table 4: Prevalence of brucellosis among cattle in relation to age

\begin{tabular}{|c|c|c|c|c|c|c|c|c|c|}
\hline \multirow{2}{*}{ Age(year) } & \multirow{2}{*}{ Samples } & \multicolumn{2}{|c|}{ RBPT } & \multicolumn{2}{c|}{ BAPAT } & \multicolumn{2}{c|}{ TAT } & \multicolumn{2}{c|}{ RT } \\
\cline { 3 - 10 } & + & $\%$ & + & $\%$ & + & $\%$ & + & $\%$ \\
\hline$<1$ year & 4 & 1 & 25 & 1 & 25 & 1 & 25 & 1 & 25 \\
\hline $1-<2$ & 25 & 1 & 4 & 1 & 4 & 1 & 4 & 1 & 4 \\
\hline $2-<3$ & 41 & 3 & 7.32 & 3 & 7.32 & 3 & 7.32 & 3 & 7.32 \\
\hline $3-<4$ & 45 & 5 & 11.11 & 2 & 4.44 & 2 & 4.44 & 2 & 4.44 \\
\hline $4-<5$ & 16 & 5 & 31.25 & 5 & 31.25 & 4 & 25 & 4 & 25 \\
\hline $5-<6$ & 20 & 1 & 5 & 1 & 5 & 1 & 5 & 1 & 5 \\
\hline $6-<7$ & 15 & 3 & 20 & 1 & 6.67 & 1 & 6.67 & 1 & 6.67 \\
\hline$>7$ & 14 & - & - & - & - & - & - & - & - \\
\hline
\end{tabular}


Table 5: Prevalence of brucellosis among sheep in relation to location

\begin{tabular}{|l|c|c|c|c|c|c|c|c|c|}
\hline \multirow{2}{*}{\multicolumn{1}{c|}{ Location }} & \multirow{2}{*}{ Samples } & \multicolumn{2}{c|}{ RBPT } & \multicolumn{2}{c|}{ BAPAT } & \multicolumn{2}{c|}{ TAT } & \multicolumn{2}{c|}{ RT } \\
\cline { 3 - 10 } & & + & $\%$ & + & $\%$ & + & $\%$ & + & $\%$ \\
\hline El-Rashda & 13 & - & - & - & - & - & - & - & - \\
\hline Mout & 18 & - & - & - & - & - & - & - & - \\
\hline El-Farafra & 30 & 2 & 6.67 & 2 & 6.67 & 1 & 3.33 & 1 & 3.33 \\
\hline El-Hendaw & 40 & 4 & 10 & 3 & 7.5 & 3 & 7.5 & 3 & 7.5 \\
\hline El-Owinat & 35 & - & - & - & - & - & - & - & - \\
\hline El-Qasr & 25 & - & - & - & - & - & - & - & - \\
\hline Gharb El-Mouhoub & 19 & 1 & 5.26 & - & - & - & - & - & - \\
\hline
\end{tabular}

Table 6: Prevalence of brucellosis among sheep in relation to age

\begin{tabular}{|c|c|c|c|c|c|c|c|c|c|}
\hline \multirow{2}{*}{ Age(months) } & \multirow{2}{*}{ Samples } & \multicolumn{2}{|c|}{ RBPT } & \multicolumn{2}{c|}{ BAPAT } & \multicolumn{2}{|c|}{ TAT } & \multicolumn{2}{c|}{ RT } \\
\cline { 3 - 9 } & & + & $\%$ & + & $\%$ & + & $\%$ & + & $\%$ \\
\hline$<12$ & 13 & - & - & - & - & - & - & - & - \\
\hline $15-18$ & 18 & - & - & - & - & - & - & - & - \\
\hline $21-24$ & 25 & 1 & 4 & - & - & - & - & - & - \\
\hline $27-30$ & 15 & 1 & 6.67 & 1 & 6.67 & - & - & - & - \\
\hline $33-36$ & 32 & - & - & - & - & - & - & - & - \\
\hline $36-48$ & 52 & 3 & 5.77 & 3 & 5.77 & 3 & 5.77 & 3 & 5.77 \\
\hline$>48$ & 25 & 2 & 8 & 1 & 4 & 1 & 4 & 1 & 4 \\
\hline
\end{tabular}

Table 7: Prevalence of brucellosis among goats in relation to location

\begin{tabular}{|c|c|c|c|c|c|c|c|c|c|}
\hline \multirow{2}{*}{ Location } & \multirow{2}{*}{ Samples } & \multicolumn{2}{|c|}{ RBPT } & \multicolumn{2}{c|}{ BAPAT } & \multicolumn{2}{c|}{ TAT } & \multicolumn{2}{c|}{ RT } \\
\cline { 2 - 10 } & + & $\%$ & + & $\%$ & + & $\%$ & + & $\%$ \\
\hline El-Rashda & 15 & - & - & - & - & - & - & - & - \\
\hline Mout & 15 & - & - & - & - & - & - & - & - \\
\hline El-Farafra & 22 & 2 & 9.09 & 2 & 9.09 & 1 & 4.55 & 1 & 4.55 \\
\hline El-Hendaw & 20 & 3 & 15 & 3 & 15 & 3 & 15 & 3 & 15 \\
\hline El-Owinat & 10 & - & - & - & - & - & - & - & - \\
\hline El-Qasr & 8 & 1 & 12.5 & 1 & 12.5 & 1 & 12.5 & 1 & 12.5 \\
\hline $\begin{array}{c}\text { Gharb El- } \\
\text { Mouhoub }\end{array}$ & 10 & 1 & 10 & 1 & 10 & 1 & 10 & 1 & 10 \\
\hline
\end{tabular}


Table 8: Prevalence of brucellosis among goats in relation to age

\begin{tabular}{|c|c|c|c|c|c|c|c|c|c|}
\hline \multirow{2}{*}{ Age(months) } & \multirow{2}{*}{ Samples } & \multicolumn{2}{|c|}{ RBPT } & \multicolumn{2}{c|}{ BAPAT } & \multicolumn{2}{c|}{ TAT } & \multicolumn{2}{c|}{ RT } \\
\cline { 3 - 10 } & & + & $\%$ & + & $\%$ & + & $\%$ & + & $\%$ \\
\hline$<12$ & 10 & - & - & - & - & - & - & - & - \\
\hline $15-18$ & 7 & 1 & 14.29 & - & - & - & - & - & - \\
\hline $21-24$ & 11 & 1 & 9.09 & 1 & 9.09 & 1 & 9.09 & 1 & 9.09 \\
\hline $27-30$ & 25 & 3 & 12 & 3 & 12 & 3 & 12 & 3 & 12 \\
\hline $33-36$ & 25 & - & - & 1 & 4 & - & - & - & - \\
\hline $36-48$ & 13 & 1 & 7.69 & 1 & 7.69 & 1 & 7.69 & 1 & 7.69 \\
\hline$>48$ & 9 & 1 & 11.11 & 1 & 11.11 & 1 & 11.11 & 1 & 11.11 \\
\hline
\end{tabular}

Table 9: Prevalence of brucellosis among humans in New Valley Governorate

\begin{tabular}{|l|c|c|c|c|c|c|c|}
\hline \multirow{2}{*}{ Sex } & \multirow{2}{*}{ Samples } & \multicolumn{2}{|c|}{ RBPT } & \multicolumn{2}{c|}{ TAT } & \multicolumn{2}{c|}{ RT } \\
\cline { 3 - 8 } & & + & $\%$ & + & $\%$ & + & $\%$ \\
\hline Female & 55 & 5 & 9.09 & 5 & 9.09 & 3 & 5.45 \\
\hline Male & 55 & 4 & 7.27 & 3 & 5.45 & 3 & 5.45 \\
\hline Total & 110 & 9 & 8.18 & 8 & 7.27 & 6 & 5.45 \\
\hline
\end{tabular}

Table 10: Prevalence of brucellosis among humans in relation to residence

\begin{tabular}{|c|c|c|c|c|c|c|c|}
\hline \multirow{2}{*}{ Residence } & \multirow{2}{*}{ Samples } & \multicolumn{2}{|c|}{ RBPT } & \multicolumn{2}{|c|}{ TAT } & \multicolumn{2}{c|}{ RT } \\
\cline { 3 - 8 } & & + & $\%$ & + & $\%$ & + & $\%$ \\
\hline Rural & 90 & 9 & 10 & 8 & 8.89 & 6 & 6.67 \\
\hline Urban & 20 & - & - & - & - & - & - \\
\hline
\end{tabular}

Table 11: Prevalence of brucellosis among humans in relation to age

\begin{tabular}{|c|c|c|c|c|c|c|c|}
\hline \multirow{2}{*}{ Age(year) } & \multirow{2}{*}{ Samples } & \multicolumn{2}{|c|}{ RBPT } & \multicolumn{2}{c|}{ TAT } & \multicolumn{2}{|c|}{ RT } \\
\cline { 3 - 8 } & & + & $\%$ & + & $\%$ & + & $\%$ \\
\hline$<6$ & 8 & - & - & - & - & - & - \\
\hline $6-20$ & 12 & 1 & 8.33 & 1 & 8.33 & 1 & 8.33 \\
\hline $21-40$ & 63 & 7 & 11.11 & 6 & 9.52 & 4 & 5.35 \\
\hline $41-60$ & 18 & 1 & 5.56 & 1 & 5.56 & 1 & 5.56 \\
\hline$>60$ & 9 & - & - & - & - & - & - \\
\hline
\end{tabular}


Table 12: Prevalence of brucellosis among humans in relation to occupation

\begin{tabular}{|c|c|c|c|c|c|c|c|}
\hline \multirow{2}{*}{ Occupation } & \multirow{2}{*}{ Samples } & \multicolumn{2}{|c|}{ RBPT } & \multicolumn{2}{|c|}{ TAT } & \multicolumn{2}{c|}{ RT } \\
\cline { 3 - 8 } & & + & $\%$ & + & $\%$ & + & $\%$ \\
\hline Farmers & 22 & 1 & 4.55 & 1 & 4.55 & 1 & 4.55 \\
\hline Veterinarians & 8 & 1 & 12.5 & 1 & 12.5 & - & - \\
\hline Veterinary attendants & 7 & 1 & 14.29 & 1 & 14.29 & 1 & 14.29 \\
\hline Butchers & 6 & 1 & 16.67 & - & - & - & - \\
\hline Housewives & 36 & 5 & 13.89 & 5 & 13.89 & 3 & 8.33 \\
\hline Technicians \& nurses & 16 & - & - & - & - & - & - \\
\hline Children & 15 & - & - & - & - & 1 & 6.67 \\
\hline
\end{tabular}

Table 13: Summarized results of the positive cases of human brucellosis

\begin{tabular}{|c|c|c|c|c|c|c|c|c|}
\hline \multirow{2}{*}{ No. } & $\begin{array}{c}\text { Age } \\
\text { (year) }\end{array}$ & Sex & Occupation & \multirow{2}{*}{ RBPT } & \multirow{2}{*}{ TAT } & \multirow{2}{*}{ RT } & \multicolumn{2}{|c|}{ ELISA } \\
\hline 1 & 13 & Male & Student & - & - & + & - & - \\
\hline 2 & 22 & Male & Butcher & + & - & - & + & + \\
\hline 3 & 39 & Male & Vet. attendant & + & + & + & + & + \\
\hline 4 & 35 & female & Housewife & + & + & - & + & + \\
\hline 5 & 33 & female & Housewife & + & + & + & + & + \\
\hline 6 & 40 & female & Housewife & + & + & + & + & + \\
\hline 7 & 21 & female & Housewife & + & + & + & + & + \\
\hline 8 & 20 & Male & Veterinarians & + & + & - & + & + \\
\hline 9 & 54 & Male & Farmer & + & + & + & + & + \\
\hline 10 & 25 & female & Housewife & + & + & - & + & + \\
\hline
\end{tabular}

\section{DISCUSSION}

Seroprevalence of brucellosis among cattle in New Valley Governorate Table (1) was $10.56 \%, 7.78 \%, 7.22 \%$ and $7.22 \%$ detected by using RBPT, BAPAT, TAT and RT, respectively. The prevalence detected by RBPT was higher than that reported by Shalaby et al., 2003 (8.84\%) and Nossair, 2005 (9.6\%) however, it was lower than that recorded by Fayed et al., 2002 (22.03\%). The prevalence detected by BAPAT was higher than that reported by Aggad, 2003 (3.5\%) and was lower than that estimated by Aggad and Boukraa, 2006 (31.5\%). Prevalence detected by TAT was higher than that recorded by El-Ansary et al., 2001 (5\%) and Aggad, 2003 (2.9\%) however, it was lower than that reported by Fayed et al., 2002 (21.48\%). The prevalence detected by RT was higher than that recorded by Noha, 2005 (3.5\%) and was lower than that obtained by Fayed et al., 2002 (21.29\%) and Nossair, 2005 (9.6\%). 
Seroprevalence of brucellosis among the examined sheep (Table 1) was $3.89 \%, 2.78 \% 2.22 \%$ and $2.22 \%$ detected by using RBPT, BAPAT, TAT and RT, respectively. The prevalence detected by RBPT was lower than that recorded by Noha, $2005(12.4 \%)$. The prevalence detected by BAPAT was higher than that estimated by Montasser, $1999(1.61 \%)$ and was lower than that obtained by Nossair, 2005 (14.8\%). The prevalence detected by TAT was higher than that detected by Montasser, 1999 (1.34\%) and was lower than obtained by Shalaby et al., 2003 (8.45\%) and Abdel -Azeem et al., 2005 (4.6\%). The prevalence detected by RT was higher than that recorded by Seddek, $1999(1.1 \%)$ and was lower than that reported by Nossair, 2005 (14.8\%).

Seroprevalence of brucellosis among goats in New Valley Governorate (Table 1) was 7\%, 7\%, 6\% and 6\% detected by using RBPT, BAPAT, TAT and RT, respectively. Prevalence of brucellosis detected by RBPT was higher than that recorded by Shalaby et al., $2003(2.65 \%)$ and Abdel-Azeem et al., 2005 (3.29\%). It was lower than that obtained by Omar et al., 2000 (33.3\%). The prevalence detected by BAPAT was higher than that detected by Aggad, 2003 (3.05\%) and Noha, 2005 (0.93\%) and was lower than that reported by EL-Bauomy (1989) who detected a prevalence rate of $19.5 \%$. The prevalence detected by TAT was higher than that recorded by EL-Ansary et al., 2001 (4\%), and Abdel -Azeem et al., 2005 (3.29\%) however, it was lower than that reported by Soliman, 1998 $(8.6 \%)$. By using RT, the prevalence of brucellosis obtained was higher than that detected by Shalaby et al., 2003 (4.92\%), and Aggad, 2003 (2.6\%). It was lower than that detected by EL-Bauomy (1989) who estimated a prevalence of $8.04 \%$. Brucellosis could not be detected among camels in New Valley Governorate by using all mentioned serological tests (Table 1), this result agrees with El-Ansary et al. (2001). However, other studies revealed the presence of brucellosis among camels (Omar et al., 2000 and Abdel Azeem et al., 2005).

Data showed in Table (2) revealed that the prevalence of brucellosis among cattle and sheep was higher among females than males. It is referred to keeping females on the farm for long time while, male spends little time in farm. Brucellosis was detected only in female goats with rate of $10.77 \%$ detected by RBPT and BAPAT and $9.23 \%$ detected by using TAT and RT.

Data illustrated in Table (3) shows the prevalence of brucellosis among cattle detected by using RBPT, BAPAT, TAT and RT, respectively was higher in El-Hendaw $(25 \%, 18.75 \%, 15.63 \%, 15.63 \%)$, followed by EL-Farafra $(18.18 \%, 12.12 \%, 12.12 \%, 12.12 \%)$ then Gharb EL-Mauhoub $(12.5 \%, 12.5 \%, 8.33 \%, 8.33 \%)$ and Mout $(8.33 \%)$. The lowest prevalence 
was observed in EL-Kasr $(6.25 \%, 0 \%, 6.25 \%, 6.25 \%)$ and we could not detect brucellosis in EL-Rashda and EL-Owinat.

By using RBPT, BAPAT, TAT, RT, Table (4) illustrate the prevalence of brucellosis among cattle in relation to age. It was highest at age of $4-<5$ years $(31.25 \%, 31.25 \%, 25 \%, 25 \%)$, followed by calves less than 1 year $(25 \%)$, then age $6-<7$ years $(20 \%, 6.67 \%, 6.67 \%, 6.67 \%)$, age $3-<4$ years $(11.11 \%, 4.44 \%, 4.44 \%, 4.44 \%)$ and age $2-<3$ years $(7.32 \%)$ the lower prevalence was observed at age $5-<6$ years $(5 \%)$ followed by age $1-<2$ years $(4 \%)$.

From studying the effect of location on the prevalence of brucellosis among sheep (Table 5), the highest prevalence was detected in EL-Hendaw $(10 \%, 7.5 \%, 7.5 \%, 7.5 \%)$ followed by EL-Farafra $(6.67 \%$, $6.67 \%, 3.33 \%, 3.33 \%$ ), then Gharb EL-Mauhoub (5.26\%, 0\%, 0\%, 0\%) detected by using RBPT, BAPAT, TAT and RT, respectively. While, brucellosis could not be detected among sheep in EL-Rashda, Mout, ELOwinat and EL-Kasr. The high percentage of positive cases among sheep in EL-Hindaw, EL-Farafra, and Gharb EL- Mauhoub may be attributed to the presence of large private brucella infected sheep flocks and keeping of infected ones in these flocks which help in the transmission of infection.

In relation to age, the results illustrated in Table (6) showed that the highest prevalence of brucellosis among sheep was at age $>48 \mathrm{~m}(8 \%, 4 \%$, $4 \%, 4 \%)$ followed by age $27-30 \mathrm{~m}(6.67 \%, 6.67 \%, 0 \%, 0 \%)$ then age $36-48$ $\mathrm{m}(5.77 \%, 5.77 \%, 5.77 \%, 5.77 \%)$ and the lower prevalence was at age 21$24 \mathrm{~m}(4 \%, 0 \%, 0 \%, 0 \%)$ detected by using RBPT, BAPAT, TAT, RT, respectively. It has been noted that the susceptibility to infection in sheep increases after sexual maturity especially with pregnancy (Noha, 2005).

The data illustrated in Table (7) clarify the relation between location and prevalence of brucellosis among goats, the prevalence was high in EL-Hendaw (15\%) followed by EL-Qasr (12.5\%) then Gharb ELMauhoub (10\%); EL-Farafra (9.09\%, 9.09\%, 4.55\%, 4.55\%) detected by using RBPT, BAPAT, TAT and RT, respectively however, brucellosis couldn't be detected in EL-Rashda, Mout and EL-Owinat and it is attributed to good sanitary measures applied at that places.

Table (8) show the relation between age and prevalence of brucellosis among goats by using RBPT, BAPAT, TAT and RT revealed that the highest prevalence observed at age $15-18 \mathrm{~m}(14.29 \%, 0 \%, 0 \%$, $0 \%$ ) followed by age $27-30 \mathrm{~m}(12 \%)$ then age $>48$ years $(11.11 \%)$; age $21-24 \mathrm{~m}(9.09 \%)$ while, the prevalence was at age 36-48 $\mathrm{m}(7.69 \%)$ followed by age $33-36 \mathrm{~m}(0 \%, 4 \%, 0 \%, 0 \%)$, respectively.

Prevalence of human brucellosis in New Valley Governorate (Table 9) was $8.18 \%, 7.27 \%$ and $5.45 \%$ detected by using RBPT, TAT, RT, 
respectively. The prevalence detected by using RBPT was higher than that recorded by Abou-Eisha, 2001 (5.1\%) and lower than that detected by Nossair, 2005 (14.3\%). The prevalence detected by TAT seems to be similar to that obtained with Abdel-Ghany (1999). While, it was higher than that obtained by Schelling et al., 2004 (2\%) and Asmaa et al., 2005 $(1.29 \%)$. Moreover, our result was lower than that estimated by Shaalan et al., 2002 (21\%) and Nossair, 2005 (14\%). The prevalence detected by RT was higher than that reported by Samaha et al. (2002) (2\%) and lower than that reported by Nossair, 2005 (14\%).

The prevalence of human brucellosis in relation to sex (Table 9) pointed out that the brucellosis in females $(9.09 \%, 9.09 \%$, and $5.45 \%)$ was higher than males $(7.27 \%, 5.45 \%, 5.45)$ detected by using RBPT, TATand RT, respectively. This result agrees with Asmaa et al. (2005) and Nossair (2005). In the contrary Colmenero et al. (2006) recorded that the prevalence was higher in males than females. The high infection rate in females may be attributed to increased exposure to infected livestock or increased susceptibility of women to the disease in the Bedouin pastoralist's society. (Cooper, 1992).

Table 10 shows the effect of residence on human brucellosis and revealed that brucellosis observed only in rural areas with rates of $10 \%$, $8.89 \%$ and $6.67 \%$ detected by using RBPT, TAT \&RT, respectively. This may be due to the close contact with livestock and the social habits that occur in rural areas such as skinning of still born lambs and kids as well as crushing the umbilical cord on newborn lambs and kids with their teeth which may increase the risk of infection (Koler, 1987).

The effect of age on human brucellosis prevalence (Table 11) revealed that the age-wise positivity was maximized $(11.11 \%, 9.52 \%$, $6.35 \%$ ) at age group 21-40 years, followed by age group 41-60 years (5.56\%). This result agrees with EL-Taweel (1999) who reported that the highest prevalence of human brucellosis was at age group 20-40 years this may be referred to the fact that the majority of workers in veterinary field, abattoir and animal attending aged 20-40 years (Wafaa et al., 2003) and disagrees with Asmaa et al. (2005) who detected the highest infection rate among those of age group 51-60 years.

Data presented in Table (12) throw the light on the relationship between human brucellosis prevalence and nature of occupation. The highest prevalence was observed among butchers (16.67\%) followed by veterinary attendants (14.29\%), housewives (13.89\%), veterinarians (12.5\%) while, the lowest prevalence was observed among children (6.67\%) followed by farmers $(4.55 \%)$. These results disagree with Nossair (2005) who detected the higher prevalence rate among veterinarians. The 
high infection detected among butchers may be attributed to the direct contact with animal carcasses (Wafaa et al., 2003). Moreover, it may be due to the bad habits of butchers in eating raw meat. Infection of veterinarians and veterinary workers due to handling cases of abortion and retained placenta or during vaccination with attenuated live vaccine (Williams, 1982). While, the infection of housewives and farmers may be attributed to close contact with infected animals. Moreover, infection of children related to consumption of raw milk.

ELISA was used to confirm the positive human brucella cases. All the positive human cases diagnosed by RBPT, TAT and RT were positive by using ELISA except for one case (case No. 1) which was negative (Table 13). Humoral response including IgM and IgG was detected in all of the positive cases by ELISA. Case No. 1 was positive only by RT which may be attributed to the cross reaction of brucella antigen preparation with other organisms including Yersinia enterocolitica serotype O: 9, Vibrio cholera, Francisella tularensis, E.coli O157:H7 and Salmonella serotype O:30 (Moyer et al., 1991). Cases No.s 3, 5, 6, 7 and 9 were positive by using all serological tests used. However, cases No.s 4, 8 and 10 were positive by using all serological test except RT which was negative this may be due to the fact that IgM antibodies are usually in excess to the IgG antibodies in acute brucellosis and thus blocking phenomenon becomes evident at low dilutions also, it may be due to the precipitating activity of Rivanol solution on the IgM. Brucellosis couldn't be detected by TATand RT in case No.2 this may be due to that the antibody titer couldn't reach the measuring level and thus it is considered false negative.

\section{REFERENCES}

Abdel-Azeem, K.; Hashad, M.; Abbas, B. and Abdel-Latif, S. (2005): Serosurvey on brucellosis in farm animals in Al-Qassim region of Saudi Arabia. J. Egypt. Vet. Med. Assoc. 65 (1): 201-211.

Abou-Eisha, A.M. (2001): Brucellosis among persons at high-risk occupation in Suez Canal area, Egypt. Assiut Vet. Med. J. 46 (91): 22-33.

Aggad, H. (2003): Serological studies on animal brucellosis in Algeria. Assiut Vet. Med. J. 49 (98): 121-130.

Aggad, H. and Boukraa, L. (2006): Prevalence of bovine and human brucellosis in Western Algeria: comparison of screening tests. East Mediterr. Health J. 12 (1-2): 119-128.

Alton, G.G. (1990): Brucella melitensis, 1887 to 1987 cited in animal brucellosis by K.Nielsen and J.R. DunCan / CRC Pren. Baston. 
Asmaa, A.A. Hussen; Amal, A.M. Sayed and Mohamed, A. El-Feki (2005): Seroepidemiological study on human brucellosis in Assiut Governorate. The Egyptian Journal of Immunology 12 (1): 49-56.

Boschiroli, M.L.; Faulongne, V. and O'callaghan, D. (2001): Brucellosis: a world wide zoonosis. Curr. Opin. Microbiol. 4 (1): 58-64.

Colmenero, J.D.; Munaz-Roca, N.L.; Bermudez, P.; Plata, A.; Villalobos, A. and Reguera, J.M. (2006): Clinical findings, diagnostic approach, and outcome of Brucella meltensis epididymo-orchitis . Diag. Microbial. Infect. Dis. 57 (4): 367-372.

Cooper, C.W. (1992): Prevalence of antibody to brucella in symptomatic well individuals in Saudi Arabia. J. of Trop. Med. Hyg. 95, 140-142.

El-Ansary, E.H.; Mohamed, B.A.; Hamad, A.R. and Karom, A.G. (2001): Brucellosis among animals and human contacts in Eastern Sudan. Saudi Med. J. 22 (7): 577-579.

El-Bauomy, E.E. (1989): Some studies on brucellosis in sheep and goats. M.V.Sc. Thesis, Fac.Vet. Med.Cairo Univ.

El-Taweel, A.H. (1999): Brucellosis information workshop, Ramallah, Oct. 19-20, Country reports Cited in Refai (2003): Brucellosis in animal and man in Egypt. J. Vet. Sci. 37: 1-31.

Fayed, A.A.; Ammar, K.M.; Al-Gaabary, M.H. and Osman, S.A. (2002):

Role of Brucella abortus strain 19 and RB51 vaccine in cattle brucellosis protection. J. Egypt. Vet. Med. Assoc. 62 (60): 279-288.

Kolar, J. (1987): Control of Brucella melitensis; brucellosis in developing countries. Annal del Institute Pasteur. Microbiolgie 138: 122-126.

Montasser, A.M. (1999): Some epidemiological and diagnostic studies on ovine and caprine brucellosis in Egypt. 5th sci. cong., Egyptian Society for Cattle Disease, Assiut; 99-106

Moyer, N.P.; Holcomb, L.A. and Hausler, W.J. (1991): Brucella in Manual of Clinical Microbiology, $5^{\text {th }}$ Ed. (By A. Balows, W.J.; Hausler. K.1.; Hermann, H.D.; Isenberg and H.J. Shadomy, pp.457-462. American Society for Microbiology, Washington. D.C.

Noha, H.M. (2005): The use of ELISA (Enzyme Linked Immunosorbent Assay) for diagnosis and epidemiology of Brucella infection in some farm animals and humans in Assiut Governorate. M.V.Sc. Thesis, Fac. Vet. Med. Assiut Univ.

Nossair, M.A. (2005): Brucellosis as a zoonotic disease in Behera and Alexandria provinces. M.V.Sc. Thesis, Fac. Vet. Med. Alex. Univ. 
Omar, M.K.; Sjerve, E.; Holstad, G.; Woldehiwel, Z. and Macmillan, A.P. (2000): Prevalence of antibodies to Brucella species in cattle, sheep, goats, horses and camels in the state of Eritrea; Influence of husbandry system. Epidemiol Infect. 125 (2): 447-53.

Refai, M. (2003): Brucellosis in animal and man in Egypt. Egypt. J. Vet. Sci. 37: 1-31.

Schelling, E.; Diguimbaye, C.; Daoud, S.; Nicolet, J.; Zinsstag, J. (2004): Seroprevalences of zoonotic diseases in nomads and their livestock in Chari - Baguirmi, Chad. Med Trop (Mars). 64 (5): 474-477.

Seddek, S.R. (1999): Serological studies on Brucella infection in cattle, sheep and goats in Assiut Governorate. Assiut Vet. Med. J. 42(83): 216-227.

Shaalan, M.A.; Memish, Z.A.; Mahmoud, S.A.; Alomari, A.; Khan, M.Y.; Al-Muneef, M. and Alalola, S. (2002): Brucellosis in children: Clinical observation in 115 cases. Int. J. Infect. Dis. 6(3): 182-186.

Shalaby, M.N.H.; Ghobashy, H.M.; El-Bauomy, E.M. Saleh and Wafaa, M.A. (2003): Prevalence of brucellosis among animal species in some governorates in Egypt. $7^{\text {th }}$ Sci. Cong., Egyptian Society for Cattle Disease, 7-9 Dec., Assiut. Egypt. pp. 271-282.

Soliman, S.A.M. (1998): Studies on brucellosis in farm animals with reference to public health importance in Suez Canal district. Ph.D. Thesis, Fac. Vet. Med. Suez Canal Univ.

Waffaa, S.M.A.; Ghobashy, H.M.; El-Bayoumi, E.M. and Shalaby, M.N.H. (2003): Diagnisis of human brucellosis among animal farm workers and patients with fever of unknown origin using both conventional and recent techniques. $7^{\text {th }}$ Sci. Cong., Egyptian Society for Cattle Disease, 7-9 Dec., Assiut, Egypt.

Williams, F. (1982): Brucellosis, Medicine Textbook, $2^{\text {nd }}$ Ed, Oxford University, Oxford. 